\title{
Az euróövezet válságrendezésének lehetséges szcenáriói - mit mondanak az elméletek?
}

\author{
Benczes István: Válság és válságrendezés a Gazdasági és Monetáris \\ Unióban - a pénzügyi és gazdasági integráció forgatókönyvei címú \\ könyvének bemutatása
}

\section{Potential Scenarios for the Eurozone Crisis Management - What do the Theories Tell Us?}

\section{Review - István Benczes: Crisis and Crisis Management in the Economic and Monetary Union - Scenarios for the Monetary and Economic Integration}

A 2008-as pénzügyi és gazdasági világválság negatív következményei súlyosan érintették az Európai Unió (EU) tagállamait, az euróövezetben kialakuló szuverén adósságválság pedig kérdések sorát vetette fel az integráció működésével és jövőjével kapcsolatban. A Gazdasági és Monetáris Unió (GMU) egyben tartása, stabilizálása, valamint hosszabb távú átalakítása jelentős kihívás elé állította a tagállamokat, hiszen az alapvető közös érdekek mellett sok tekintetben eltérő nemzeti preferenciák is megjelennek. Ennek következtében egyáltalán nem triviális az, hogy az EU részéről milyen taktikai és stratégiai válaszok születtek és születnek az európai gazdasági kormányzással összefüggésben.

Benczes István legújabb könyve, amely az Akadémiai Kiadó gondozásában jelent meg, éppen arra tesz kísérletet, hogy egy hatalmas mennyiségű szakirodalmat átölelő kutatás eredményeként a válságrendezés eddigi tapasztalatainak elméleti rendszerezésével hozzájáruljon az államadósság-válság kapcsán kialakult akadémiai (és akár gyakorlati) diskurzushoz. A könyv sok tekintetben újdonságnak és egyben hiánypótlónak

Kollárik Ferenc egyetemi tanársegéd, Nemzeti Közszolgálati Egyetem, Államtudományi és Nemzetközi Tanulmányok Kar, Közgazdaságtani és Nemzetközi Gazdaságtani Tanszék, e-mail: kollarik. ferenc@uni-nke.hu 
tekinthető az európai integrációval foglalkozó magyar szakirodalomban. Az euróövezeti válságról és válságkezelésről készültek már ugyan magyar nyelvű könyvek, azonban a most bemutatott monográfia néhány jelentős ponton eltér ezektől.

Elsőként érdemes megemlíteni, hogy a szerző nagyszerűen kapcsolja össze a nemzetközi politika, valamint az integráció különféle elméleteit az EU „hétköznapi” politikai gazdaságtani folyamataival. Ezzel is igyekszik rámutatni arra, hogy a sokszor „hasznavehetetlennek” kikiáltott elméletek/teoretikus összefüggések - kellő gondosság mellett - nagyon is jól alkalmazhatók, és jelentős segítséget (támpontot) nyújthatnak a különböző valós események leírásában és interpretációjában. Az európai integráció magyar nyelvű irodalmának vonatkozásában ezt azért is érdemes külön hangsúlyozni, mert - megítélésünk szerint - a szó szoros értelmében vett elméletek méltatlanul háttérbe szorulnak, sőt szinte alig vannak jelen a hazai EU (vagy akár a tágabb értelemben vett regionális) -integrációs kutatásokban. Meggyőződésünk (és ezt a könyv is alátámasztja), hogy az elméleti rendszerezés és megközelítés nem öncélú, hanem egy olyan hasznos módszertani eszközt képes a kutató kezébe adni, amely a puszta deskriptív elemzésen túlmenően akár az „előrejelzésben” (lehetséges szcenáriók kidolgozásában) is komoly segítséget nyújthat.

Az eddigiekből következően az is elmondható, hogy a könyv alapvetően multidiszciplináris megközelítésű, amennyiben a nemzetközi kapcsolatok különféle elméleti keretein belül, illetve ezek segítségével próbálja magyarázni a Gazdasági és Monetáris Unió közgazdasági, illetve politikai gazdaságtani folyamatait. Ez a megközelítés többek között lehetőséget teremt arra is, hogy a vizsgált területet komplexebben, a különböző tudományterületek interakcióin keresztül lehessen bemutatni.

Végül, de nem utolsósorban ki kell emelnünk, hogy bár a könyv rendszerezi az euróövezet válságrendezésének eddigi tapasztalatait és eredményeit, ezt mégis más módon teszi, mint a témával foglalkozó legtöbb hazai írás. Jelen esetben ugyanis a szerző célja nem az események (kronologikus) leírása és ismertetése, hanem az, hogy a múltbeli és jelenleg is zajló folyamatokból a már említett elméletek segítésével különböző lehetséges forgatókönyveket (integrációs kimeneteket) építsen fel. E tekintetben a könyv a gazdasági integrációt - mint integrációs fokozatot - alkalmazza függő változóként, azonban e változó lehetséges értékeiben (értsd: a kimenetelekben) viszonylag jelentős mértékú variancia figyelhető meg. A lehetséges trajektóriák azonosítását és elkülönítését két változó beiktatásával (kooperáció és a centralizáció) végzi el a szerző. Mindkét változó alternatív, így lényegében egy négy potenciális kimenetet tartalmazó mátrixhoz jutunk el, amelyben mozogva az együttmúködés és centralizáció viszonyától függően a következő eredmények adódhatnak: dezintegráció, inkrementális reform, hegemónia, valamint mélyülés. Jóllehet mind a négy kimenet egyfajta tiszta modellt (Benczes István megfogalmazásában: ideáltipikus helyzetet) tár az olvasó elé, a valóságban természetesen ezeknek számos különböző ötvözete is szóba jöhet, mint lehetséges integrációs kimenet. A szerző szavaival élve az elkülönítés segítségével mégis lehetőség nyílik arra, hogy „megértsük az egyes alternatívák belső logikáját, feltárjuk azokat az ok-okozati viszonyokat, amelyek az adott kimenetet tartóssá vagy képlékennyé tehetik". ${ }^{1}$

Benczes István: Válság és válságrendezés a Gazdasági és Monetáris Unióban - a pénzügyi és gazdasági integráció forgatókönyvei. Budapest, Akadémiai Kiadó, 2020. 33. 
A könyv logikus felépítésű, gondolatmenete jól követhető, mondanivalóját pedig rendkívül érdekes összefoglaló/csoportosító ábrák és táblázatok egészítik ki, amelyek nagyban segítik e szerteágazó és komplex területnek a rendszerezését. Szerkezetét tekintve három főbb egységre tagolódik.

A bevezető részben ismerteti a monográfia célját, a kutatással kapcsolatos kérdéseket és sejtéseket foglalja össze, valamint bemutatja a könyv szerkezetét. Egyebek mellett itt kap helyett a fent említett függő változó, illetve a lehetséges forgatókönyvek táblázatos definiálása is. A bevezetést követően két nagyobb rész keretében folytatódik a téma tárgyalása.

$\mathrm{Az}$ első rész (Integrációelméletek) a téma szempontjából releváns elméleteket ismerteti. Elsőként a gazdasági integráció értelmezéseit és definícióit járja körül, majd összefoglalja az egymással rokonságban álló neofunkcionalizmus, illetve történeti (historikus) institucionalizmus összefüggéseit. Ezt követően a különféle államközpontú megközelítésekkel (klasszikus intergovernmentalizmus, a nemzetközi kapcsolatok racionalista elméletei, a kétszintú játékok, liberális intergovernmentalizmus, valamint új kormányköziség) foglalkozik, amelyek az államnak mint politikai entitásnak az elsődlegességét hangsúlyozzák az integrációs folyamatok magyarázatában. A fejezetet függelék zárja, amely az államközpontú magyarázatokban előszeretettel használt főbb játékelméleti szituációkba/modellekbe nyújt betekintést.

A második rész (A válságrendezés forgatókönyvei) a kooperáció-centralizáció mátrixban azonosított lehetséges kimeneteleket bontja ki részletesen, mindegyiket önálló fejezet formájában. A dezintegráció forgatókönyve (4. fejezet) kapcsán kitér a világgazdaság történetében fennállt monetáris uniók felbomlásának kérdésére, valamint az optimális valutaövezetek elméletét alkalmazza a kilépés lehetőségének elemzésére. Végül azt a kérdést járja körül, hogy mit mondanak az integrációelméletek a dezintegrációról. $\mathrm{Az}$ 5. fejezet a kis lépések stratégiáját (az inkrementális reformokat) elemzi a görög kimentés, az Európai Stabilitási Mechanizmus (ESM) és a Költségvetési Paktum eseteit felhasználva. A szerző a válságrendezés harmadik szcenáriójaként a hegemóniát jelöli meg, amellyel a 6. fejezet foglalkozik. Itt a hegemón stabilitás elmélettel (HSE) közelíti a gazdasági kormányzás átalakítását, és az újraegyesült Németország - mint (lehetséges) hegemón - szerepét hangsúlyozza. A 7. fejezet a negyedik lehetséges alternatívát (a mélyülést) vázolja fel a bankunió és a fiskális unió esetein keresztül. A könyv összefoglaló fejezettel zárul, amely már konkrét esetekkel tölti fel a mátrixot, beazonosítva, hogy a válságrendezés egyes elemei melyik szcenárióba illeszkednek (illeszthetők) leginkább. ${ }^{2}$ Zárszóként ismét utalás történik arra, hogy tulajdonképpen mi is volt (illetve mi nem volt) a könyv célja, és mitől tekinthető újszerűnek. A szerző megfogalmazásában ez úgy foglalható össze, hogy „nem az egyes elméletek feltevésrendszerének és következtetései jóságának igazolása volt a cél, hanem a megfigyelt események [...] vagy lehetséges történések [...] oly módon történő interpretálása, hogy abban megfelelően hasznosulhassanak a választott elméletek fogalmi és módszertani elemei. [...] Nyitott kérdés, hogy e folyamatok teljes megértése a már meglévő keretek újszerű kombinációja révén vagy forradalmian új elméletek és módszerek kidolgozása által valósul-e majd meg a jövőben."3

Benczes (2020) i. m. 279.

Uo. 297-298.

Európai Tükör 2020/3. 
Összességében elmondhatjuk, hogy Benczes István új könyve kiválóan ötvözi a Gazdasági és Monetáris Unió válságrendezésének akadémiai/elméleti, valamint gyakorlati (politikai gazdaságtani) megközelítéseit. A könyv nemcsak rendszerezi a rendkívül sokrétű és összetett válságrendezés eseményeit és összefüggéseit, de mindezt egy merőben új és - a hazai szakirodalomban eddig nem igazán alkalmazott - módszertani keretrendszerben teszi. Így azon túl, hogy a könyv a maga nemében hiánypótló műnek tekinthető, a szélesebb értelemben vett társadalomtudományokban jártas, és a GMU iránt érdeklődő olvasók számára is hasznos olvasmány lehet.

\section{Felhasznált irodalom}

Benczes István: Válság és válságrendezés a Gazdasági és Monetáris Unióban - a pénzügyi és gazdasági integráció forgatókönyvei. Budapest, Akadémiai Kiadó, 2020. DOI: https://doi.org/10.1556/9789634543480 